\title{
EUROPE AND ITS SCHOLARLY COMMUNITIES
}

\section{THOMAS WOLFE}

The essay explores the idea that we think of works of scholarship as documents marking belonging to communities, rather than as the texts of a socially ungrounded science. It uses examples from social scientific works that study contemporary European construction to suggest the importance of incorporating into one's view apparently contradictory viewpoints. Keywords: scholarship, European construction, community, disciplinarity and interdisciplinarity.
Prispevek obravnava premiso, da znanstvene študije obravnavamo kot besedila, ki izražajo pripadnost določenemu strokovnemu krogu oziroma znanstveni skupnosti in ne kot tekste, ki so produkt družbeno nevtralne znanosti. Na osnovi primerov iz družboslovja, ki obravnavajo ustroj sodobne Evrope, avtor ugotavlja, kako pomembno je, da znanstveniki v svoj pogled na predmet obravnave vključijo tudi pousem protislovna si stališca.

Ključne besede: znanstveni izsledki, evropski ustroj, skupnost, disciplinarnost in interdisciplinarnost.

I.

This short essay is in the most general way about "European construction," "the construction of Europe," although not in the usual sense of construction. The common sense of the word implies something being put together according to an either implicit or explicit plan, but there has been and is no detailed instruction book for "Europe." There is no implicit or "folk" knowledge of how to make it, nor of what it will look like when it is finished. For here is one thing we can say with complete certainty: "Europe" is a work in progress, it will never come to the complete fulfillment of itself, as when a chair fulfills itself by being sat on. As a place (let's call it a "continent," knowing full well how fuzzy that term is as it applies to the earth's surface at the western end of Asia) it will keep evolving over time, the people who live there will combine the new and the old in attempts to sustain and transform themselves.

More concretely: Europe is not a person on whose behalf others speak, it is not a company whose share price would measure the success of the construction, it is not a soccer team whose place in the standings would mark what has been done and what more there is to do. With the phrase "European construction," something different is meant: it refers to the totality of means by which people write, speak, act, argue, struggle, etc., on behalf of "Europe." It is dependent upon media for its existence and transmission (otherwise it would be just another fleeting throught in someone's head), and it has shown its 
vital importance by being "embodied" in institutions where people's work is dedicated to the further realization of this idea. And again as with all ideas, the meaning of "Europe" changes, depending on the contexts of its enunciation. This is because people react to ideas as we react to everything else in our environment: pollen, noise, bright light, hate speech, romantic verses about the nation, arguments about knowledge economies: we process them and adjust our practice in complex calibration with our/an environment.

What we can say with some confidence is that the idea "Europe" has been appearing in more and more places in the last sixty years; it has become institutionalized in the evolving offices of a series of "European" institutions, and it has and continues to generate many other ideas, articulated in many other statements. Today there are innumerable journals that take "Europe" as their object; Europe exists an object of pedagogy for children from Lisbon to Tallinn, and in the last sixty years there has emerged a sizable corpus of European law. "Europe" has become one of the core subjects of political discourse within European countries, for it has become impossible to be a politician in one of these countries without having a position on "Europe." It is the subject of enormous debate and discussion by intellectuals, philosophers, sociologists, for whom Europe's future is an urgent subject.

Perhaps we could say that "Europe" is at the core of broad range of diverse communities, each of which poses Europe as an ethical problem to be addressed. In this essay I examine this ethical problematization of Europe as it appears in three scholarly communities. After all, Europe is being constructed not only by "politicians" doing things out there in the world, but also by scholars whose ideas, images, and ways of thinking and doing contribute to the ongoing flows of European invention. The first frames Europe in the terms of an historical narrative that takes as its task to articulate the difference between the two halves of the 20th century. The urgent task of this community of historians today is to sort out the century's loose ends, to narratively wrap up that tumultuous century by establishing histories where there were none before and by sorting through that history to address the controversies that still linger. The second constructs a Europe that is, by contrast, never far from its catastrophe, for it studies the radical right. It is concerned with the power of groups whose political role models were responsible for Europe's descent into barbarity. The third community of scholars take Europe as neither a narrative hero, or a possible scene of repetition, but as a glaring contradiction: it is constructed by scholars who examine the flip side of Europe's universal values, namely the control of population at Europe's borders.

These scholarly communities are not monolithic; they contain within them energetic debates and controversies, but here I am less interested in the debates than in the communities they help construct. Indeed, I refer to these communities using just a handful of texts, but they are enough to enable me to pose a few questions about the ethical dimensions of the scholarly life, a dimension that comes not only from the practices of authorship and communication, but also from the languages that one takes up to construct a world. The contrast I am pointing out is not between ethical and unethical practices, but between different options for self-creation and self-assertion. 
II.

Historians have always had powerful public voices. Their authority was founded on the assumption that after giving a careful, truthful account of the past, it would be possible to pass judgment on it, thereby establishing a worthy and just attitude in the present. A number of historians, interpreters of Europe's postwar era, leave us in their works with the following picture:

The transformation of Europe in the twentieth century seems divided neatly into two halves: a first half full of ideological conflict, nationalist wars, and failed politics, and a second half marked by recovery and remarkable economic, political, and cultural growth and change. In the first half, Europe shattered itself, in the second it healed itself. In the first half, Europeans were racists and eugenicists, imperialists and colonialists, chauvinists and misogynists; in the second half, Europeans became champions of human rights, equal rights for women, the protection of the environment-an entire range of progressive positions that constructed an image of tolerance and understanding.

This story of crisis followed by recovery, catastrophe followed by consensus, is a way of grasping the incredibly complicated and overwhelmingly intricate events that unfolded in the course of that tumultuous time. They draw a line between a then and a now, for no matter how troubling politics today looks in the EU or in its member states or in those states bordering the EU and seeking membership, we can always recall the deep history of the 20th century, and appreciate the fact that at least nationalist armies are not mobilizing for continent wide conflict; there are no all-powerful demagogues stirring up distorted passions in their national populations; there are no colonial empires managed from European capitals dedicated to an arrogant, exploitative, and hypocritical project of civilization or enlightenment. Europe is just a normal, vital part of the world, affluent and picturesque, governed by liberal politics and capitalist markets.

Different historians stress different parts of this story; James Sheehan has described how in the postwar era Europe lost its martial spirit, while Tony Judt has described the convergence of European countries on democracy and capitalism (Sheehan 2006). The Europe about which we are to feel good is of course geopolitical Europe, a Europe that is known by training our eyes on the politics of European states, on the presence or absence of assertions of state power, and on the competition and cooperation between states that shape condition the lives of citizens. These narratives are useful to the degree that the reader wants what the historian can provide best: a sense of sweep and process, schemas of development and change. The ethical terrain that is made possible here is one on which a process of national construction unfolds: the task posed by this history is what attitude to take towards national origins. The history suggests that above all Europeans must be realistic and find some good balance between their national commitments and European 
ones, whatever they might be. This provides the hint of Euroscepticism that one sometimes finds in these histories: because Europe's past is only understandable in terms of the trials and tribulations of nations, Europe's member-states will of course be the units of Europe's future as well.

And yet what these, specifically historical, narratives cannot provide is a sense of a present moment as anything other than the place where their narratives have left off. They cannot by definition provide an answer to a question like, what is happening in Europe today? This is not the territory the historian patrols, after all. When we feel secure after reading such works, it is because we extrapolate, or as the word suggests, we give a shine to the future with the past. But here is a profound ethical problem: how to feel and think after a history? Does it compose a subject that is grounded in a present, equipped, as it were, to sort through what matters from what clearly doesn't? Or can any lesson left in us by a history be useful? Perhaps we should go further and suggest that historians might be the last people we should look to for reassurance, comfort or certainty since they are trained to pay attention to making stories (fictions) from facts (documents, dates), while the future is as yet factless, and the present is full of movement, impressions, and sensations. Of course the Europe that is today will have a history someday, this moment will become the stuff of historical narratives constructed by historians who will sift through newspapers and letters, memos and speeches, government files and radio transcripts, web archives and hard drives, with the goal of generalizing from this mass of expression a sense of how this moment came into being. But when we take comfort from this standard postwar narrative we are taking comfort in a certain hope that the Europe that has been built is too big to ever collapse, has too many safeguards and redundancies, and is viewed by too many people as vital and indispensable to ever be dismantled.

We can leave it at that and go on about our business. But if we wanted to investigate matters in a bit more depth we can easily find help in the social sciences, which have for at least century claimed a certain expertise on the present, an expertise created by the consolidation of methods that were understood to produce reliable, true knowledge. Social scientists collect data and apply various interpretive grids to make the data intelligible; they collect and generalize with the result that a piece of the world is clarified, that is, brought under scientifically valid description. So, for example, Europe is at this very moment crawling with sociologists and political scientist who are busy making sense of the present by taking polls, analyzing the last European Parliament vote, doing content analyses of speeches, coding interviews and designing surveys. And a good portion of them are not especially calm or confident or optimistic about the future, for they are tracking an unpleasant growth in Europe's extended body: racism, chauvinism, xenophobia, hate crimes and hate speech, race-based hooliganism, stereotyping, ugly entertainment, condescension, and the list goes on. They are doing this not in one or two or even three countries, but across the continent. And they construct another scholarly community, with its own ethical constitution.

Here we might look to a 2008 book by the political scientist, Cas Mudde, whose 
introduction participates in the work of constructing this community. As to the interest among political scientists in the far right, Mudde notes, "Whereas the (edited) books on party families like the Christian democrats or liberals can be counted on the fingers of one or two hands, those on the populist radical right (irrespective of the term used) might already outnumber the combined total of books on all other party families together." Thus Mudde feels he must justify the appearance of yet another book on the subject. After noting that radical right parties are, along with the Greens, the only new parties to appear on both halves of the continent, Mudde writes, "Seen in this light, it does not seem strange to have yet another book on this topic. After all, the populist radical right is the only successful new party family in Europe. Moreover, given the unprecedented horrors of the Second World War, and the more recent nativist wars in the Balkans, the destructive threats to liberal democracy of the populist radical right seem reason enough for the extensive study of the phenomenon. Not surprising then, that the populist radical right is one of the few academic topics that one can study without having to defend the relevance of one's choice." And then, as if seeking to cement his justification, he recounts a story from his lectures. Whenever he reminds his audiences of just how small the votes for radical rightwing parties have been in Europe, "no one in the audience sees this as a good reason for me to either leave or question my almost ten-year career in this subfield of political science." Far from demanding a justification for his research, his audiences' "reaction is one of utter disbelief or annoyance: 'why are you playing down the dangers of the extreme right?"” (Mude Cass)

Here is another complex ethical terrain, one whose most obvious trait is its self-evidence. The scholarly community forms itself around the obviousness of a threat to liberal society (a threat inherent in democratic systems) posed by skilled manipulators of mass opinion. Political scientists like Mudde play the functional role of sentinel, monitoring the public sphere, keeping tabs on those groups that have the potential to resurrect the totalitarian politics of earlier times. There is no room here for ambiguity or hesitation; in fact, a reading of the past gives this mission that much more justification: if only we had paid more attention, the catastrophe of the earlier parts of the century would not have occurred. If a bigger fuss had been made about the tactics and appeal of the Nazi party in the early 1930s, for example, it may have been possible for other parties and politicians to turn potential voters away from them. All this provides impetus to pay attention to the now. This community is therefore organized around the collection and formulation of concise, comparable information, the kind of knowledge produced by quantitative political science and sociology. It orients itself towards the arena of electoral behavior and the task of making sense of what people do and think when they vote. This is a community dedicated to the security and health of the body politic.

Finally, at the frayed end of the otherwise taught fiber of social science lies anthropology, which has prided itself on a different way of knowing the present and putting it under description, namely, ethnography, the writing (down) of culture. No consensus exists about whether or not this method provides a means of delivering truth that is "scientific," and 
yet most anthropologists delight in the image of their discipline as being the only social science that likes to get its feet wet and hands dirty. No other social science goes in for such detail, or cares so much about things that on the face of it seem so utterly insignificant. A picture of Europe constructed by anthropologists and ethnographers would be a bewildering mosaic, each stone of which consists of an intense examination of a single small terrain: a village in a valley, a set of offices, streets in a certain city, computer screens, houses and bars, suburbs, a bog, and on and on, each a small, particular scene.

All this means that the scholarly communities of anthropologists are of a different sort than the ones constructed by historians and political scientists. There is no familiar social function that ethnographers fulfill; rather, their works provide raw materials with which to construct or deconstruct positions about pressing matters. They work from publicizing otherwise invisible and unimportant sites that nevertheless provide a jolt to sensibilities. The "Europe" of ethnographers is a Europe of specific people in specific institutions, or as in the work of Sabine Hess, of specific people caught up in multiple institutions. ${ }^{1}$ Hess is an ethnographer of migration, and she and her colleagues, as well as those political philosophers who ground their writings on the work of ethnographers like Hess, show that Europe is still full of unnecessary violence, violence done today not for nationalist reasons, in the course of the centuries' long competition between European states, but by European government(s) in the name of Europe, in order to maintain the zone of peace and prosperity that Europe has become. They represent in scholarly languages the processes by which people seek to enter Europe and are prevented from doing so by a variety of means. Looking closely over the shoulders of ethnographers like this, we see the ugly, everyday work of policing at Europe's borders, where the task is keep out those who do not and cannot fit in. This showing is itself a fraught activity, since unlike the visible worlds that provide the material for historians and political scientists, ethnographers of this kind set themselves the task of pursuing the marginal, mapping worlds in which actors do not want to be seen. This raises difficult methodological issues that are both an expression and yet another source of anthropology's ongoing identity crisis.

III.

My suggestion that a work of scholarship is both an invitation to join and a manifestation of belonging to a community has certain implications that might be worth exploring. Foremost among these might be recognition that any given community is constructed around

1 See her talk, "De-naturalizing Transit Migration: theory and methods of an ethnographic regime analyses," IMISCOE-Conference: Transit Migration in the European Space Istanbul, (http://docs. google.com/gview?a=v\&q=cache:qOVnTOFT504J; www.compas.ox.ac.uk/fileadmin/files/pdfs/ Non_WP_pdfs/Tranist_Migration_in_Europe_Koc_University_/3\%2520Transit\%25203\%2520 Hess_Methodology.pdf+IMISCOE-Conference:+Transit+Migration+in+the+European+Space,+Ista nbul+18.-20.4.2008\&hl=en\&gl=us). 
partial views and that it is useful to imagine engagement with a community which holds the "opposite" position. We might ask ourselves, for example, about the balance between continuity and discontinuity in the story of the postwar. Maybe something can be gained by seeing the postwar era as a kind of suspension of war and conflict rather than the scene of its "disappearance." Writers like Judt and many others recognize the presence of war in the form of Europe's memory problems, but perhaps there is a deeper connection to be explored between war and consumption, war and a consumer imaginary, along the lines of Kristin Ross's book Fast Cars, Clean Bodies (1996). Nor should the disappearance of the military class and the figure of the soldier be interpreted as meaning the disappearance of the forms of power for which military institutions were a vehicle.

Likewise with the study of the radical right. Perhaps there is reason to examine the community of scholars whose mission is to keep tabs on the return of fascism, not because the danger does not exist, but because it comes from a different direction, namely from what consensus around liberal, capitalist politics has created. It seems important to entertain the possibility that the question, from which door or window might fascism enter Europe today?, might be the wrong question, and that a compelling standpoint might emerge from the thought, what investment have our selves and institutions come to have in forms of totalitarian politics in the widest sense? How have our societies domesticated certain forms of totalitarian power? How much is something unpleasant already here, rather than being only a vividly imagined threat? These questions are pursued by very different kinds of community than that of quantitative political science, and to engage them fully would require at the very least reflection upon one's worldview.

And finally, the community of heroic anthropological critics of European migration policies can be examined for its assumptions and unexamined foundations. Here we might want to explain the violence done at the margins in much more complex terms than those provided by a notion of universal human rights, as if this were a problem with a policy or strictly legal solution. Another scholarly community might argue that the community of engaged intellectuals prowling for the marginal seems always threatened by a transformation into an advocacy group. They might argue that actions at the "margins" emerge in close connection with complex and contradictory feelings, convictions, and conditions at the "center." The anxiety about European belonging is something that needs its own community of inquirers, one that will most likely not offer its members an aura of moral righteousness.

In conclusion, by highlighting the community nature of scholarship I mean to draw attention to the ways that ideas and arguments are social and mediological; they project communities of the like-minded who then become for all intents and purposes real. We might give thought as we write to the kinds of invitations that we are sending as we examine European construction, and to the kinds of sociality we are projecting as we analyze and argue. So here is a general invitation: if there is anything to the protean idea of the European citizen, then it would be a person who constructs him or herself not from principles 
that are deemed correct according to one community, but from a breadth and depth of an understanding of scholarly community itself.

\section{REFERENCES}

Cas, Mudde

2008 Populist Radical Right Parties in Europe. Cambridge: Cambridge University Press, 1-2.

Judt, Tony

2008 Postwar. London: Penguin.

Ross, Kristin

1996 Fast Cars, Clean Bodies: Decolonization and the Reordering of French Culture, Cambridge: MIT Press, 1996.

Sheehan, James

2006 Where have all the soldiers gone? New York: Houghton Mifflin.

2008 Tony Judt, Postwar, London: Penguin.

\section{EVROPA IN NJENE ZNANSTVENE SKUPNOSTI}

Prispevek obravnava premiso, da znanstvene študije obravnavamo kot besedila, ki izražajo pripadnost določenemu strokovnemu krogu oziroma znanstveni skupnosti, in ne kot tekste, ki so produkt družbeno nevtralne znanosti. Na osnovi primerov iz družboslovja, ki obravnavajo zgradbo sodobne Evrope, avtor ugotavlja, kako pomembno je, da znanstveniki v svoj pogled na predmet obravnave vključijo tudi povsem protislovna si stališca. Tako kot politične ali antropološke studije tudi zgodovinski teksti navadno navajajo argumente, na podlagi katerih se bralec priključi enemu ali drugemu taboru. Vendar pa utegne biti precej pomembnejše, da se znanstveniki nimajo več za zagovornike te ali one intelektualne ideje, ampak za raziskovalce, ki se pomikajo skozi več znanstvenih skupnosti. Prenašanje načina komuniciranja, ki je značilno za politične forume, $v$ katerih zagovorniki določene ideje stojijo na različnih bregovih, vakademske sfere, je dokaj slab prikaz intelektualnih prizadevanj. Ne smemo si namreč prizadevati, da bi zmagale določene ideje ali da bi dosegli kompromis, pač pa moramo ustvariti novo skupnost raziskovalcev. $V$ sodobnih raziskavah evropskih zadev so tri področja, na katerih bi bilo moč oblikovati take nove znanstvene skupnosti. Ta tri področja si zastavljajo naslednja vprašanja: Katero zgodovinsko usmeritev iz obdobja po drugi svetovni vojni lahko uporabimo za primeren okvir, v katerem bomo razmišljali o sedanjosti? Na kaj bi morali biti še posebno pozorni pri radikalni desnici, ko razmišljamo o političnem potencialu evropskih družb? Kakšen je pomen priseljevanja v Evropsko unijo in pa prepričanja, da moramo to priseljevanje nadzirati? Kar zadeva prvo vprašanje, je moč zaslediti velik pomen, ki ga pripisujemo splošnemu prepričanju, da predstavlja leto 1945 
zelo pomembno prelomnico v evropski zgodovini. A namesto da bi ta prelom imeli za znanstveno resničen, so nekateri prepričani, da je to zgolj predstava, ki koristi določenim krogom, in da bi bilo morda prav tako koristno, če bi obdobje po drugi svetovni vojni obravnavali kot nekaj nepretrganega. Bistveno je, da si človek predstavlja, kako sodeluje z znanstveno skupnostjo, ki trdi, da vzrok za posebne poteze obdobja po letu 1945 ni v tem, da je bilo brez vojn, ampak da je nadaljevanje določenih tehničnih in znanstvenih predstav, ki usmerjajo obravnave populacij. Taka skupnost je bolj podobna skupnosti filozofov kot pa zgodovinarjev, to pa je dejstvo, ki ima pomembne implikacije. Ena izmed najvidnejših posledic pogleda na znanstvene izsledke kot na dokumente skupnosti in ne kot na izraz znanstveno utemeljenih raziskav je ta, da človek gleda na pripadnike drugih disciplin kot na osebe in ne kot na zastopnike vede oziroma protagoniste $v$ določeni raziskavi. Taka sprememba zornega kota bi imela velike posledice za izobraževanje in za akademsko kulturo kot celoto.

Prof. Dr. Thomas C. Wolfe, Department of History, University of Minnesota,wolfe023@umn.edu 
